\title{
Latas Colapsantes
}

\author{
Maria João M. Curto \\ INETI - Portugal \\ Maria Domitila de Menezes* \\ amoita@mail.telepac.pt \\ Escola Superior de Educação de Lisboa - Portugal
}

\section{Informações do Artigo Resumo}

Histórico do Artigo Utilizando uma lata ou garrafa de bebida vazia, este artigo apresenta um

Criado em Novembro de 1998 experimento de fácil execução, para ilustrar alguns conceitos de FísicoQuímica para alunos do nível fundamental.

\section{Palavras-Chaves \\ Aquecimento \\ Resfriamento \\ Pressão \\ Físico-química \\ Compressão \\ Expansão}

Chemkeys. Licenciado sob Creative Commons (BY-NC-SA)

\section{Objetivo}

Mudanças de estado e seus efeitos sobre materiais

\section{Atenção!}

Ler o procedimento com muita atenção, antes de começar a experiência. Não realizar o experimento sem o acompanhamento do seu professor. Peça ajuda em caso de dúvida.

\section{Material Necessário}

- Colher de sopa

- Latas de bebida vazias

- Placa de aquecimento

- Pinças de laboratório

- Água

- Recipiente com água fria

\footnotetext{
* Autor para contato
}

Segurança

- Manusear o material quente com precaução.

- Não aquecer a lata sobre chama muito forte.

- Nunca fazer esta experiência com garrafas de vidro ou de plástico duro.

- Leia mais sobre segurança em outros artigos do site.

Procedimento

1. Colocar 1 colher de sopa de água na lata vazia

2. Aquecer a lata até a água ferver (o vapor sai pela abertura da lata). Deixar a água ferver durante cerca de 30 segundos.

3. Usando pinças (cuidado para não se queimar!!!), segurar na lata, invertê-la depressa e mergulhá-la imediatamente na água fria que está no recipiente

4. Observar o que acontece à lata. 
- Ao aquecer a lata contendo água, a água ferveu e passou ao estado de vapor.

- Ao esfriar a lata subitamente, o vapor de água condensou dentro dela, o que fez reduzir a pressão no seu interior e provocou o seu colapso.

- Com esta experiência, observou o efeito de variações de pressão sobre os materiais. $\mathrm{O}$ resultado pode ser observado na Figura 1.

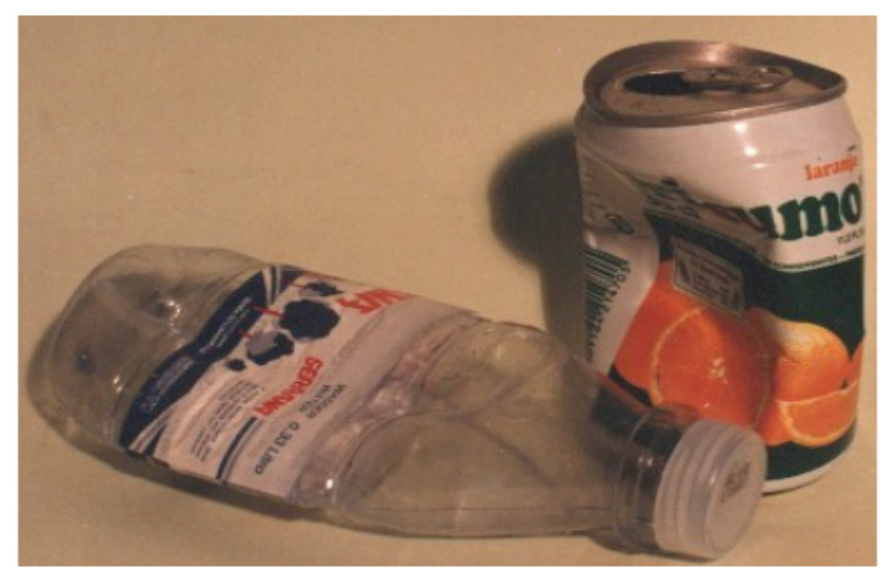

Figura 1 - Como ficam as latas e garrafas de plástico após a experiência

Nem todas as latas dão bons resultados nesta experiência, pois a liga metálica utilizada pode ser suficientemente resistente à compressão.

A experiência também pode ser realizada com garrafa de plástico. Neste caso:

1. Encher a garrafa com água quente e despejá-la rapidamente colocando logo em seguida a tampa

2. Mergulhar a garrafa em água fria. Observar e registrar. 